Article

\title{
A Clash of Conventions? Participation, Power and the Rights of Disabled Children
}

\author{
Ralph Sandland \\ School of Law, University of Nottingham, Nottingham, NG7 2RD, UK; E-Mail: ralph.sandland@nottingham.ac.uk
}

Submitted: 28 March 2017 | Accepted: 17 July 2017 | Published: 26 September 2017

\begin{abstract}
This article considers the neglected topic of the relationship between the Convention on the Rights of Persons with Disabilities and the Convention on the Rights of the Child, with regard to the participation rights of disabled children. It analyses key articles in both conventions and considers relevant general comments from both convention committees (the Committee on the Rights of the Child and the Committee on the Rights of Persons with Disabilities), and their interpretation by academic contributors. The article argues that much work on this topic fails to develop an adequate understanding of power relations, and that the 'social model of disability' which underpins the disabilities convention, when applied to 'childhood' (as opposed to 'children') suggests that the implications of that convention for the participation rights of all children, not only disabled children, are profound. This is because the disabilities convention rejects the relevance of tests of capacity and 'best interests' for disabled adults, for reasons which are equally germane to disabled children, and children in general. The article concludes with discussion of the difficulties in implementing the insights derived from the analysis of the disabilities convention in substantive law in the absence of a right to freedom from age discrimination for children, and suggests other, less far-reaching, reforms that could be made this notwithstanding.
\end{abstract}

\section{Keywords}

childhood; children; disability; participation; rights; social model

\section{Issue}

This article is part of the issue "Promoting Children's Participation in Research, Policy and Practice", edited by Jo Aldridge (Loughborough University, UK).

(C) 2017 by the author; licensee Cogitatio (Lisbon, Portugal). This article is licensed under a Creative Commons Attribution 4.0 International License (CC BY).

\section{Introduction}

The United Nations Convention on the Rights of the Child (CRC; United Nations, 1989) was the first human rights convention to contain an article dedicated to disability. Article 23(1) seeks to ensure that disabled children enjoy 'a full and decent life' which includes 'active participation in the community'. Article 23(3) directs state parties towards the goal of ensuring 'the fullest possible social integration' of disabled children. In addition, Article 2 gives children a right to freedom from discrimination on various grounds including disability. Generally, the 'participation rights' of disabled children should be factored in to all actions, policies and decisions concerning or affecting children (Committee on the Rights of the Child [CCRC], 2006, para. 5).
Since 2006, the position of disabled children has been further enhanced by numerous provisions of the United Nations Convention on the Rights of Persons with Disabilities (CRPD; United Nations, 2006). The CRPD is founded on the importance of ensuring participation for disabled persons. Article 1 builds 'full and effective participation in society on an equal basis with others' into the convention's definition of disability and Article 3(c) provides that participation is one of the general principles running through the convention. Article 7, dedicated to disabled children, incorporates the best interests test, and the rights to be heard and have views taken into account, found in Articles 3(1) and 12(1) CRC, as Articles 7(2) and (3) respectively. Article 7 both guides the application of the rights found in that convention to children and acts as a bridge between the CRPD and the 
CRC. Article 7(1) affirms that 'States Parties shall take all necessary measures to ensure the full enjoyment by children with disabilities of all human rights and fundamental freedoms on an equal basis with other children' (see also preamble, para. (r)).

The interface between the CRC and the CRPD has been subject to little critical analysis (Sabatello, 2013). This may be because it is commonly understood that the CRPD merely elaborates on the rights given to children by the CRC, rather than providing new rights. I will argue, however, via an analysis which moves beyond issues around the substantive content of rights and into questions of paradigm and approach, that the potential impact of the CRPD on the CRC is profound. This arises from the adoption by the framers of the CRPD of what is called a 'social model' approach to disability, which carries within it a vision of participation which is incompatible with both the substantive content and the underlying ethos of the CRC, in terms of the latter's construction of 'the disabled child' and 'childhood'. I will first consider how children's participation has been discussed in debates around CRC participation rights, suggesting that these debates suffer from an impoverished understanding of the relationship between participation and power. I will then consider whether the social model approach is more satisfactory in this regard, both in theory and in terms of how it plays out in Article 12 CRPD, this being that convention's key article on participation rights. In the final substantive section of the article I will focus on the right to express a view and, have it taken into account, this being a cornerstone right for effective child participation in both the CRC and the CRPD. I will conclude that the main issue which the CRPD raises for the CRC is whether a 'social model of childhood' should be adopted. I argue that it should, although I concede that Rome was not built in a day, and so end by suggesting other, less contentious, changes that could be made to the way in which the CRC is interpreted, whilst we patiently await 'the dawn of a new era' promised by Kofi Annan on the day the CRPD came into existence (Bartlett, 2012).

\section{Participation, Rights and Power}

Although the rights contained in the CRC are integrated and indivisible, impacting on and informing the scope of each other, they are often categorised in terms of

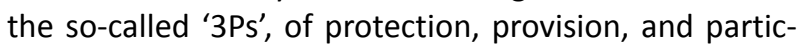
ipation. Protection and provision rights are rooted in welfarist concerns - the survival of the child, protection from harm or neglect, the meeting of needs, and the provision of services. Participation rights, by contrast, whilst depending for their efficacy or even possibility on functioning protection and provision rights, emphasise the present and future autonomy and agency of the child. At the risk of oversimplification, it can be said whilst protection and provision rights are concerned to secure the conditions of possibility for a good and meaningful life, participation rights in the $\mathrm{CRC}$ are concerned with living that life, and seek to provide appropriately modified, childfocussed, versions of traditional adult civil and political rights to self-determination and involvement in the polis. The provision of participation rights to children was one of the great innovations introduced by the CRC.

Participation rights are possessed by individual children, by groups of children-such as disabled childrenin respect of decisions which affect them, and by all children collectively. They have both a social and political aspect, requiring that children be encouraged and enabled to engage both in society, broadly understood, and in democratic processes. Participation rights do not respect the public/private divide, applying equally to parental or other domestic decision-makers (albeit that here they must interact with parental rights to raise their children and guide their development provided by Articles 18 and 5) as to public actors and institutions in their dealings with children. The single most significant participation right in the CRC is the Article 12 right to be heard and have one's views taken into account, considered by the CCRC (2003, para. 12) to be one of the four general principles (along with freedom from discrimination; upholding best interests; and the right to life, survival and development) underpinning the CRC. Other 'participation rights' are phrased as freedoms: of expression (Article 13); thought, conscience and religion (Article 14); and association and peaceful assembly (Article 15).

Supporting these primary participation rights, are rights to privacy (Article 16) and of access to media and information (Article 17). Participation is also emphasised as an aspect of other rights, such as the 'right to participate fully in cultural life and the arts' provided by Article 31, and specific groups are provided with bespoke participation rights, including disabled children, as already mentioned (Article 23) and children belonging to an indigenous minority (Article 30). Beyond this, the indivisibility of rights in the $\mathrm{CRC}$ means that all rights therein are in some sense participation rights: the right to freedom from discrimination, for example, is designed to ensure equal participation opportunities for all; the idea of best interests is swathed in normative assumptions about the benefits of participation; and Article 12 and the other rights listed above interact with other CRC provisions such as the rights to the highest standard of health (Article 24) and to education (Articles 28, 29).

The emergence of children's participation rights reflected general trends such as consumerism and user involvement, but also developments in the sociology of childhood, with new paradigms of the child as autonomous and capable replacing historical constructions grounded in notions of dependency, lack and parental authority (Tisdall, 2008; Sinclair, 2004), based on research demonstrating the significant capacities of children. As the CCRC notes in General Comment [GC] 12 (CCRC, 2009, para. 21), citing Lansdown (2005): 'Research shows that the child is able to form views from the youngest age, even when she or he may be unable to express them verbally'. Human rights discourse embraced and 
amplified these new constructions of the child as subject (Thomas, 2007). This entails that the substantive content of participation rights respect the autonomy of the child, with 'participation' requiring something more than mere involvement or consultation. Participation rights should enable children to "learn how their views and those of adults are taken into account and shape the outcome of such processes' (CCRC, 2009, para. 3), and 'should not only be a momentary act, but the starting point for an intense exchange between children and adults on the development of policies, programmes and measures in all relevant contexts of children's lives' (CCRC, 2009, para. 13).

Child participation is understood to offer present and future benefits to the child or children concerned, including enhanced life experiences, the development of a sense of self-worth, and of capacities, confidence, and so on. It is also said to mean 'better outcomes, both for young people and for organisations' (Kirby, Lanyon, Cronin, \& Sinclair, 2003, p. 18). More generally, better participation better upholds the legal rights of children and the obligations of governments and other actors towards them, and as such enhances democracy. Given this multiplicity of aims, it is not always clear how the concept of 'successful' participation should be understood. Much effort has been expended on developing strategies, policies, practices, and protocols designed to actualise, normalise and measure participation and participation rights (Kirby et al., 2003; Lundy, 2007), such as Hart's ubiquitous adaptation of the 'ladder of participation' (Hart, 1992). And as far as 'social' participation in contexts such as education, leisure or sport is concerned, the notion of 'well being' has been shown to be positively correlated to the efficacy of participation rights (Lloyd \& Emerson, 2016), so that greater levels of 'well being' - with social scientists devising ways to measure changes-can be taken as indicative of more or less successful projects to realise participation rights. Things are trickier when it comes to political participation. The main mechanism used by adults - the right to vote-is not available to children. There is a 'participation gap' which Nolan (2010, p. 768) sees as 'deeply problematic' because it 'not only poses a serious obstacle to the conceptualisation of children as full "citizens" but undermines the legitimacy of the outputs of so-called representative democratic decision-making bodies in relation to children's rights issues'; and attempts have been made, by Nolan and others (Cohen, 2005), to devise ways to address the democratic deficit which have involved developing the notion of citizenship in novel ways.

The absence of the right to vote in the CRC reflects the reluctance of adult populations to share political power with children, and this reluctance has frequently been reported by research on participation in other contexts (VIPER, 2013). Concern has been expressed that too often participation initiatives remain on the lower rungs of Hart's ladder of participation: 'few' of those studied by Badham 'showed any tangible results' of participation initiatives, and that 'One of the reasons for this emerging chasm between process and outcome is adult policy makers' and professionals' lack of attention to power in participation' (Badham, 2004, p. 144), which tends towards tokenism rather than genuine partnership as envisaged by the CCRC. The issue here can be understood in terms of the balance between autonomy and benevolence: participation implies agency and, to some extent at least, constitutes the displacement of benevolence-as well as of adult power and authority over children. This is certainly the view of the CCRC, which sees participation rights as needed by children to address 'many longstanding practices and attitudes, as well as political and economic barriers' (CCRC, 2009, para. 4). The relationships involved are paradoxical, however. Arguments for more and better participation are commonly addressed not to children but to adults - national governments and NGOs, health and education establishments, parents and others-as the principal actors (Tisdall, 2008). Participation for children is seen to be 'dependent on the cooperation of adults' (Lundy, 2007, p. 929). It is they who must give (some) power to children.

Whilst in one sense clearly correct, this sort of analysis endorses a model of power as a 'thing' over which something like ownership rights can be held, and alienated. I would rather align myself with Foucault, who holds that, rather than being something which can be possessed, power is better understood as something which is exercised:

what defines a relationship of power is that it is a mode of action which does not act directly and immediately on others. Instead, it acts upon their actions: an action upon an action, on existing actions or on those which may arise in the present or the future. (Foucault, 1983, p. 220)

This view has various implications: power is not seen in abstract terms but rather as embedded in human relationships; it is diffuse and polycentred; alinear and multidirectional; and it should be studied in terms of effects not intentions. Gallagher gives the example of the right to vote in school council elections. What this actually means depends, amongst other things, on numerous pupil-pupil, pupil-teacher, pupil-school, and teacherschool, relations. If any of these relations change 'the power which pupils are able to exercise will also be transformed' (Gallagher, 2008, p. 399). That adults have given children in the school the right and power to vote, with the intention of fostering participation in the running of the school, is of little relevance to whether those intentions are mirrored in their effects, and tells little about the actual benefits, level, nature or intensity of the participatory experience.

For Foucault, power understood in terms of 'actions upon actions' is characteristic of the way that modern government functions. The idea of good government 'depends not upon crushing the agency of subjects into sub- 
mission, but rather in cultivating this agency in particular ways' entailing a 'subtle interplay between the hierarchical, coercive power of the governor over the governed, and the governed subject's power over herself, which we might call her autonomy' (Gallagher, 2008, p. 401). Modern government aims to construct subjects who are amenable to modern government (Foucault, 2007, p. 99). For example, whilst Article 28 CRC provides a right to education for all children, Article 29 requires state parties to operate their education systems so as to both develop the personality, talents, abilities, and capacities of the child to their fullest potential, and to prepare children 'for responsible life in a free society'. That is, the aims of education include the production of autonomous adult citizens who will share the vision of good government and who, as good, responsible, citizens, will themselves be governable. The risk of government, however, when it is the government of freedom, is that freedom will exceed its allocated place. The autonomous subject, educated by the state to be a good and governable citizen, might exercise that autonomy to resist governance. As Foucault puts it, 'there are no relations of power without resistances' and resistance 'exists all the more by being in the same place as power; hence, like power, resistance is multiple' (Foucault, 1980, 142). From such a perspective, notions of power based on ownership or possession, and which see it as alienable, seem hopelessly inadequate to capture all the competing and conflicting actions and flows which together constitute the operation of power and resistance in modern societies, and limit our ability fully to evaluate the risks and benefits of participation rights for disabled children.

Although Foucault has applied his ideas to the governance of children (Foucault, 2006, ch. 9), more work is needed to think through the ways in which ideas principally concerned with the governance of adult populations might function in the context of children's rights. As contemporary, human rights-grounded, discourses of childhood embrace notions of autonomy and agency, and outlaw control strategies using physical force, it is perhaps to be expected that strategies to encourage compliance in adult populations are also now also utilised for child populations. Moreover, Foucault's model of the modern operation of power-which he sees as being, initially at least, derived from the power of a father over his family (Foucault, 2007, pp. 94-95)-suggests that parents should be seen as part of the governmental structure regulating the autonomy of children (Articles 5, 18.1, $\mathrm{CRC}$ ). From this perspective, participation rights function as a mechanism to include children in their own governance, as a strategy for neutralising threats to governance (Gallagher, 2008, p. 402). Conversely, participation rights, especially the right to express a view and have it taken into account, impact on parental as much as state exercises of power. Such questions can be theorised, but their answers cannot. As mentioned above, the operation of power should be studied in terms of its effects rather than the intentions behind its deployment.
Answers to questions about how participation works in practice involve the study of outcomes, of effects, and are strictly within the realm of the empirical, as the study of actions, and actions on actions.

\section{The Social Model of Disability, Children, and Childhood}

The CRPD has, since 2006, provided disabled children with further participation rights. The CRPD is a good example of the revolution which has overwhelmed traditional concepts of disability, with the emergence of the so-called 'social model' of disability. The social model, the exact contours of which are contested (Gabel \& Peters, 2004), involves a rejection of both the 'medical model' which locates disability as an inherent, problematic quality of the individual; and the 'social welfare model', which sees social policy in terms of charity and philanthropy towards people with 'special needs'. Instead, it is a model grounded in equality, rights, and their infringement (Kanter, 2015). Social models of disability conceptualise disability as resulting from various barriers to participation that society places in the way of persons with impairments. The removal of these barriers is the mission of the social model and disability rights.

The emergence of the social model of disability has spawned a broad literature. Some criticise it as too allencompassing and at risk of denying the subjective experience of being a disabled child (Watson, 2012, pp. 194-195). Others argue that the model must be modified accordingly, and make a distinction between 'disability' (a social/cultural phenomenon which is the result of barriers placed by society in the way of participation) and 'impairments effects' (the limitations which individuals experience which are 'directly associated with or "caused by" having a physical, sensory or intellectual impairment') (Thomas, 1999, p. 42). Those who defend the model, including some closely associated with its emergence, are content to accept such views, making the point that the social model never sought to become 'an all-encompassing framework within which everything that happens to disabled people could be understood or explained' (Oliver, 2013, p. 1024). It is a modified version of the social model which underpins the CRPD. Article 1 defines 'disability' (although not exhaustively) as 'long-term physical, mental, intellectual or sensory impairments which in interaction with various barriers may hinder their full and effective participation in society on an equal basis with others', and para. (e) of the preamble refers to 'attitudinal and environmental barriers'.

Although little work has yet done on the application of the social model of disability to disabled children, various supportive critiques have emphasised that it can accommodate a broad constituency of differentiallysituated stake-holders (Shakespeare \& Watson, 1997, pp. 298-299). The Committee on the Rights of Persons with Disabilities (CCRPD) has not addressed the question 
directly, but evidently does not see a problem, applying the social model to barriers to education, play, and sport in its GC 4 (CCRPD, 2016, para. 58). Connors and Stalker (2007) have sought to measure the relative importance to disabled children of external barriers and internal impairments, which the authors (Connors \& Stalker, 2007, p. 31) and others (Watson, 2012, p. 196) understand as constituting the application of the social model to disabled children.

However, there is a need for clarity on this issue, involving a vital distinction between the application of the social model to children, and to 'childhood'. In their research, Connors and Stalker (2007) apply the model to children. But merely asking what barriers stand in the way of disabled children's participation does not capture the full implications of the model, because it leaves the concept of childhood untouched. The social model is concerned with more than challenging barriers to participation. It also involves a critique of 'disability' as an exercise of power, which holds:

(i) that the benevolence of both the medical and social welfare models mask their operation as power and control, and the imposition of the valuejudgments of the decision-maker (Banner, 2012; Holroyd, 2012), such that the CCRPD for this reason insists (CCRPD, 2014, para. 21) that the 'best interests principle' is not CRPD-compliant (see further below); (ii) that earlier models endorsed an inappropriate, individualising, focus to understanding disability; and

(iii) that the concept of 'autonomy' as that term functions in liberal discourses is 'by and large a fiction' (Mégret, 2008, p. 513) because it underplays the extent to which individual autonomy is achievable only through social and other relations.

Here, the social model overlaps with other provocative developments, including Fineman's vulnerability theory (Fineman, 2008), Nussbaum's work on the 'capabilities approach' (Harnacke, 2013), and feminist and other work on the concept of 'relational autonomy' (e.g., Mackenzie, 2014; Series, 2015). Space precludes further discussion, but it is important to appreciate that the social model of disability is embedded in a broader project to deconstruct the autonomous subject so central to liberal political and legal theories.

The CRPD is premised on the view that all persons require support to be free and autonomous, which both serves to dissolve any firm barrier, such as that between 'able' and 'disabled'; (or, significantly, although the CCRPD does not mention this) that between adult and child. In international law terms, the challenge is to the barrier between, on the one hand, civil and political rights, exercised by an autonomous subject, and, on the other, economic, social and cultural rights, essential for the realisation in practice of effective civil and political rights, which involves 'a profound process of reformulating rights’ (Mégret; 2008, p. 515). Sometimes de- scribed as a 'support paradigm' (Series, 2015, p. 80), this is the model embedded in the CRPD, and there has been to date 'a general failure to understand that the human rights-based model of disability implies a shift from the substitute decision-making paradigm to one that is based on supported decision-making' (CCRPD, 2014, para. 3). The difference between the two paradigms is that the latter posits the individual concerned, seen as having legal capacity, as the decision-maker, whereas the former removes the decision from an individual found to lack capacity, typically via an inappropriate conflation of legal and mental capacity (CCRPD, 2014, para. 15), and hands it to a third party, to be made by reference to that third party's assessment of the best interests of the individual concerned. This seen by the CCRPD as discriminatory and antithetical to the participation rights of disabled persons (CCRPD, 2014, paras. 13, 45).

Applying this model to children entails seeing 'childhood' in the same way as 'disability' - as a set of legal and other limitations imposed on the subject, over and above those resulting from, or irrespective of, their present individual abilities and capacities. This is not to impute sinister motives to adults; nor to challenge the validity or propriety of the CRC's vision of childhood as ideally occurring 'in a family environment, in an atmosphere of happiness, love and understanding' (CRC, preamble); nor to dismiss the historical and continuing importance of the CRC in and of itself, precisely for the way in it constructs children's legal personality in the discourse of rights (Freeman, 2011). But it is to recognise that childhood, and the $C R C$ as the legal expression of normative discourses of childhood, can be understood as: regulatory devices which produce normative judgments about children and child development (Gadda, 2008); systematic discrimination based on age; disempowerment; and as such, as barriers to participation. In short, it can be argued that childhood is in effect a species of disability, in the specific sense in which that latter term is deployed by the social model and the CRPD. The social model, accordingly, bites twice on the disabled child; once because she is a child and again because she is disabled. Its application to childhood involves asking questions about how power flows through discourses and actions around both childhood and disability, and their various intersections; how this power is constitutive of individuals, as in some sense the effects of power; and how it might be acted on by or for the benefit of disabled children. That is, the social model should be seen as an analysis of power relations rather than as a theory of disability.

The social model of disability was strongly endorsed by the CCRC in its CG 9 (CCRC, 2006, para. 5), meaning in the view of the committee that 'the barrier is not the disability itself but rather a combination of social, cultural, attitudinal and physical obstacles which disabled children encounter in their daily lives'. Correspondingly, 'The strategy for promoting [the] rights [of disabled children] is therefore to take the necessary action to remove those barriers' (CCRC, 2006, para, 5). This is uncontrover- 
sial as far as it goes, but as can be seen, to understand the social model only in terms of 'barriers' misses the broader, and more politically challenging, implications of a social model approach and how it might apply to disabled children. Specifically, the CCRC does not to recognise that one significant barrier confronting disabled children, and children generally, is the social, and legal, construction of childhood itself. The denial of the franchise to children is perhaps the clearest example of the point. As I will now discuss, this argument is supported by an analysis of the role that capacity plays in the construction of the child and her rights in and by the CRC, as it is here that the CRPD decisively parts company with the $\mathrm{CRC}$, and the 'best interests' approach.

\section{Children, Capacity and Supported Decision-Making in the CRPD}

The stance taken on the issue of capacity in the CPRD is ground-breaking and controversial. The key provision is Article 12. Articles 12(1)-(3) provide:

1. States Parties reaffirm that persons with disabilities have the right to recognition everywhere as persons before the law;

2. States Parties shall recognize that persons with disabilities enjoy legal capacity on an equal basis with others in all aspects of life;

3. States Parties shall take appropriate measures to provide access by persons with disabilities to the support they may require in exercising their legal capacity.

Article 12, like the CRPD generally, is grounded in an understanding that the key issues to be addressed are the historical inequalities between the rights of disabled adults compared to non-disabled adults, and discrimination against disabled persons (Dhanda, 2007). What makes it controversial is its challenge to the status quo. It seems to prohibit the use of any test of capacity which is linked to, or triggered by, a person's disability:

Legal capacity and mental capacity are distinct concepts. Legal capacity is the ability to hold rights and duties (legal standing) and to exercise those rights and duties (legal agency). It is the key to accessing meaningful participation in society. Mental capacity refers to the decision-making skills of a person, which naturally vary from one person to another and may be different for a given person depending on many factors, including environmental and social factors...Under article 12 of the Convention, perceived or actual deficits in mental capacity must not be used as justification for denying legal capacity. (CCRPD, 2014, para. 13)

The insistence that all persons have legal capacity is buttressed by the CCRPD with a corresponding reading of Article $12(3)$ as requiring supported decision-making as the norm, and the 'abolition' of substituted judgment approaches. There is no room for compromise: 'The development of supported decision-making systems in parallel with the maintenance of substitute decision-making regimes is not sufficient to comply with article 12 of the Convention' (CCRPD, 2014, para. 28). However, the CCRPD does accept that Article 12(4), which requires state parties to provide 'appropriate and effective safeguards to prevent abuse' when providing support to a person in the exercise of their legal capacity, does permit a substituted judgment to be made 'Where, after significant efforts have been made, it is not practicable to determine the will and preferences of an individual'. But even here, the task of the decision-maker is to do their best to implement the 'will and preferences' of the person in question, rather than make their own decision as to that person's best interests (CCRPD, 2014, para. 21).

A detailed examination of debates around Article 12 is beyond the scope of the present article, but in summary, most CRPD scholars are supportive, even enthusiastic about, the approach taken in the CRPD and by the CCRPD in GC 1 (Arstein-Kerslake \& Flynn, 2016). However, Richardson, herself broadly supportive, has noted $(2012$, p. 346), that the apparent contradiction in the CCRPD view -in seeing Articles 12(1)-(3) as providing that all persons have legal capacity, but conceding that Article 12(4) suggests otherwise-is hard to reconcile. Others are sanguine about the impact of the convention on domestic capacity law, and see GC 1 as a missed opportunity to clarify key issues, including the relation between Articles 12(1)-(3) and Art 12(4) (Dawson, 2015). Others still see the issue in temporal terms, of how to implement fundamental change to laws, practices and attitudes (Harnacke, 2013), given that 'sufficiently developed concepts and legislative models are not in place for legal reform to reflect the new paradigm' (Bartlett, 2014, p. 173), whilst making existing mechanisms function effectively to protect rights in the meantime.

Despite these uncertainties, it must be considered whether Article 12-in applying to 'all persons with disabilities' (Article 1, CRPD), and given that 'legal capacity is a universal attribute inherent in all persons by virtue of their humanity' (CCRPD, 2014, para. 8)-should be taken to include children. The CCRPD's view is that 'best interests' tests, as disempowering and discriminatory, do not comply with Article 12 when applied to adults (CCRPD, 2014, para, 21), but as far as disabled children are concerned, the rights approach of Article 12 is subordinate to the 'best interests' approach of Article 7:

While article 12 of the Convention protects equality before the law for all persons, regardless of age, article 7 of the Convention recognizes the developing capacities of children and requires that in all actions concerning children with disabilities, the best interests of the child...be a primary consideration' (para. 2) and that 'their views [be] given due weight in accordance with their age and maturity' (para. 3). To com- 
ply with article 12 , States parties must examine their laws to ensure that the will and preferences of children with disabilities are respected on an equal basis with other children. (CCRPD, 2014, para. 36)

This statement is, however, more ambiguous than it appears. On the one hand, it appears that the CCRPD has done what it censures in others-it recognises that disabled children have the right to equality before the law, but does not allow disabled children to exercise that right. The principle of non-discrimination should preclude a situation whereby disabled adults are entitled to greater levels of support than disabled children, yet this would seem to be the effect of children being steered away from Article 12 and into Article 7 by the CCRPD. Having stated that legal capacity tests allowing substituted judgment by third parties do not comply with the convention, the CCRPD here not only defends the use of a legal capacity test, but the most discredited version of such; a test based on 'status', which it specifically disapproves in relations to disabled adults (CCRPD, 2014, para. 15). The paradigm shift occurring around the concept of disability as reflected in the CRPD is not, it seems, in view of the CCRPD intended to apply to disabled children.

And yet, the reference to 'the will and preferences' of disabled children points otherwise. In GC 1, the CCRPD states that "The "will and preferences" paradigm must replace the "best interests" paradigm to ensure that persons with disabilities enjoy the right to capacity on an equal basis with others' (CCRPD, 2014, para. 21), Here, the CCRPD uses the term 'will and preferences paradigm' as simply another way of describing the supported decision-making paradigm, as a key aspect of the social model of disability: in the social model, the purpose of support is to assist the supported person to articulate their will and preferences in the form of decisions. In using the same term when discussing the situation of disabled children, and in the same breath as it refers to the best interests paradigm, the CCRPD seems, then, to have conflated the old and new paradigms, constructing disabled children as a moment of difference in personhood, allegedly protected but also not protected by Art.12. It is submitted that this is inconsistent with the philosophy of the CPRD. This can be seen most clearly in the way that the participation rights of disabled children to express views and have them taken into account are differentially constructed in the CPRD compared to the CRC.

\section{The Right to Express Views and Have Them Taken into Account}

This right is found in both conventions. Article 12(1) CRC provides:

States Parties shall ensure to the child who is capable of forming his or her own views the right to express those views freely on all matters affecting the child, the views of the child being given due weight in accordance with the age and maturity of the child.

Article 7(3) CRPD is similar, but imposes greater obligations on state parties:

States Parties shall ensure that children with disabilities have the right to express their views freely on all matters affecting them, their views being given due weight in accordance with their age and maturity, on an equal basis with other children, and to be provided with disability and age-appropriate assistance to realize that right.

As can be seen, Article 7(3) contains three modifications of the Article 12(1) CRC right. First, Article 7(3) unlike Article $12(1)$ refers to equality between disabled children and other children, implying that Article $7(3)$ is corrective (designed to buttress the rights that disabled children already possess under the CRC) rather than novel (designed to provide new rights). Secondly, the reference to capacity to form a view is absent from Article 7(3). It could be suggested that nothing turns on this because a view which has not been formed cannot be expressed. It can perhaps more plausibly be argued, however, that this is indicative of the general attitude of hostility towards 'capacity' tests which runs through CRPD, as discussed above.

The third difference, that Article 7(3) CRPD unlike Article 12(1) CRC requires disabled children to be 'provided with disability and age-appropriate assistance', further contradicts the claim that the CRPD is merely corrective. The right to express a view on matters which affect one, and to have that view given due weight, is essentially a civil right grounded in the state's obligation to comply with natural justice, and as such imposes 'a strict obligation to undertake appropriate measures to fully implement this right for children' (CCRC, 2009, para. 19, discussing Article 12(1) CRC). But the right to assistance in the realization of that right, guaranteed by Art.7(3) CRPD, is an entitlement or 'social' right, and the obligation on states in respect of such rights is that they need be provided for only 'to the maximum of its available resources' (Article 4(2) CRPD, see also Article 4 CRC). In conventional international human rights law terms, Art.7(3), by conflating the two types of right, and subordinating the latter to the former, undermines the distinction made by Article 4(2) CRPD and Article 4 CRC. There is no doubt, however, that this mixing of 'types' of rights, which is a feature not just of Article 7(3), but of the CRPD generally, was intentional, reflecting the social model approach towards rights (Dhanda, 2008; Mégret, 2008; Weller, 2011). As such, it is submitted that the best reading of Article $7(3)$ is that it rejects the relevance of capacity and applies a supported decision-making approach to the participation rights of disabled children.

It is unfortunate that the CCRC did not analyse or even refer to Article 7(3) in either GC 9 (2006), dealing 
with the rights of disabled children, or GC 12 (2009), dealing with Article 12 CRC rights. In GC 9, the CCRC does state that compliance with Article 12(1) requires that disabled children 'should be represented in various bodies such as parliament, committees and other forums where they may voice views and participate in the making of decisions that affect them as children in general and as children with disabilities specifically' (CCRC, 2006, para. 32). The CCRC also notes with concern that disabled children are too often not consulted about decisions to remove them from their family environment and place them elsewhere (CCRC, 2006, para. 48), and urges states to comply with Article 12(1) in this context. But other topicshealth, education, juvenile justice, civil rights and freedoms, sport and leisure, and others-are discussed without any reference to the rights in Article 12(1) or how they might apply, and there is little discussion of the rights of individual disabled children. Overall, GC 9 is very much protectionist in tone.

The Article 12 CRC rights of children are also considered in GC 12. Although as a General Comment it is appropriate that it deals with generalities, nonetheless it is striking that the position of disabled children is barely mentioned. The CCRC does state that disabled children should be 'equipped with, and enabled to use, any mode of communication necessary to facilitate the expression of their views' (CCRC, 2009, para. 21), but beyond that, disabled children are only referenced, along with indigenous children or very young children, as examples of subsets of children who have a group right to be heard under Article 12 or for whom particular considerations apply to state plans for the implementation of Article 12 rights (CCRC, 2009, paras, 9, 87). And as seen above, the participation rights of disabled children are dealt with only summarily by the CCRPD in its GC 1 .

In summary, the participation rights of disabled children have not been clarified by either committee. The CCRC has taken an approach in line with the ethos of the CRC, viewing the Article 12 rights of all children as never amounting to the right to self-determination enjoyed by all adults. This is evident in its reading of the relationship between Articles 3(1) and 12(1) CRC. The CCRC sees 'no tension' between the two articles, but 'only a complementary role of the two general principles'. Article 12(1) is 'the methodology for reaching the goal of hearing either the child or the children', whereas Article 3(1) 'establishes the objective of achieving the best interests of the child' (CCRC, 2009, para. 74). From a Foucauldian perspective, Articles 3(1) and 12(1) can be seen as 'actions on actions', and the methodological error which the CCRC makes is to view the intention behind these actions as determinative of their effects. Although in practice there will often be no tension involved in applying the two articles together, sometimes there will be. And this tension is fundamental: it is the tension between control and resistance, benevolence and autonomy. This is not to deny that a dispute can be resolved, for example whether a child's view is determinative of the outcome or not. But the resolution of the tension, irrespective of the CCRC's view, can and will only be achieved on a case by case, individualised basis, and it will be a question of the particular configuration of actions upon actions, the flows of power which can be brought to bear, in the particular situation. A child well-equipped with rhetorical and diplomatic skills, or unusual reserves of determination and belligerence, may secure a more favourable outcome from her encounter with adults than her less well-equipped peer, for example. But the point is that, whilst the nature of tension may be theorised, its resolution can only be achieved in practice and the play of actions upon actions. However, the CCRC does not even concede the (prior) stage of recognising a tension in the first place.

For the CCRC, like the CCRPD, there is never a point at which a child, however 'mature' and capacious, may decide on his or her own best interests in a way in which relevant adults disapprove (see, e.g., CCRC, 2009, paras. 29, 30 ), which leads to the conclusion that the participation rights of children are at root mechanisms for governance rather than autonomy, or the incremental recognition of autonomy is itself a mechanism for governance. Hence, the CCRC is inaccurate when it claims that 'age alone cannot determine the significance of the child's views' (CCRC, 2009, para. 29), because it is precisely age, and status as a child, which justifies this approach to participation. The CCRC is only able to reach this view by making no more than a passing and token reference to the social model of disability, the CRPD, its attempts to shift the paradigm around participation, and the implications of that, not just for disabled children, but for all children and, especially, the concept of childhood itself.

\section{Concluding Comments}

'Participation' entails engagement in relationships which are shot through with power dynamics, and hence there is a need to analyse participation rights as embroiled in this play of actions on actions. I have argued that much work on child participation has been hindered by the failure to do this. I further argued that the social model of disability, itself a critique of power relations around disability, functions similarly when applied to childhood, as opposed to children; revealing childhood itself, like disability, to be a constructed set of barriers to participation. Childhood, generally and in the CRC, may, and should, be constructed positively, recognising and celebrating the inherent worth, dignity, autonomy and developing abilities of the child. But it also encodes a set of normative assumptions about incapacity, dependency, irrationality, immaturity, which cloak the disempowerment of children thereby achieved with an appearance of justificatory adult benevolence and responsibility. It is only by acting on those assumptions that the CCPRD is able simultaneously to disapprove the application of tests of legal capacity and best interests achieved through substituted judgment for adults whilst finding no fault in their 
continued application to disabled children, and children in general. It is nonetheless striking that the CCRPD emphatically rejects and blithely endorses the use of legal capacity in the same breath.

TenBroek (2009, p. 39) has suggested that 'the main value of the [CRPD]...is that it forces us to face the contradiction between the "myth system" and "operation system" of our laws'. TenBroek's point concerns equality between adults, but it applies equally to the gap between the myth of equal protection of the laws and the reality of inadequate protection of disabled children, and children in general. The problem, though, from a legal point of view, is the absence of tools to make such an argument. The CRPD offers only protection from discrimination on the grounds of disability. The CRC also offers children protection from discrimination on the grounds of disability, as well as the other grounds in Article 2. But what is missing, from this point of view, is an explicit right to protection from discrimination on grounds of age. In a sense, the entirety of the CRC and the concept of children's rights recognises and seeks systematically to address age-related discrimination against children, and Article 2, whilst listing specific heads of discrimination, is non-exhaustive, applying broadly to 'discrimination of any kind' or based on any 'other status' of the child, which would seem to include the status of the child as child, that is, age-related discrimination (although the 'other status' component was intended to protect, for example, children born to unmarried parents: Buck, 2011, p. 125). To date, however, although Article 2 has subsequently been expanded in scope, and is now seen as prohibiting discrimination based on unlisted factors such as sexuality, or HIV status, for example, there has been little appetite to develop this possibility (Besson, 2011, p. 103; Breen, 2005). Indeed, it is common to see Article 2(1) discussed with no reference made to the possibility that it applies to age-based discrimination. But without such a right, attempts to implement the social model of childhood in the sense developed in this essay cannot get off the ground.

It may well be (thought) futile to develop a position on the participation rights of disabled children which questions the relevance of capacity and the best interests approach. There is little prospect of, and little support for, any such position (although it is not too long since the same could be said in the context of the rights of disabled persons). But less fundamental reform may be more palatable. Specifically, it is argued that the continued reliance on a 'status' approach to capacity, which holds that all below the age of 18, whatever their actual capacity, may not exercise their own rights when a third party disagrees as to their best interests, is not defensible. If international child law is not (yet) prepared to follow international disability law in abandoning tests of legal capacity and substituted judgment in favour of universal legal capacity and supported decision-making, then it can at least abandon the 'status' approach to capacity in favour of the 'functional' approach.
There should be a corresponding shift from substituted judgment to supported decision-making in the exercise of capacity. The explanation of the relationship between Articles 7 and 12 CPRD as they apply to children offered by the CCRPD does not preclude the application of the Art 12(3) right to supported decision-making to disabled children. Franklin and Sloper (2009, p. 13) have observed that knowledge regarding supported decisionmaking for adults 'has remained rather polarised from that of children's participation', and more recently the VIPER (2013) research reached the same conclusion. Supported decision-making should be the ideal for all children, but there is extra support for taking this approach to disabled children in the requirements imposed on state parties by Article 7(3) CRPD. As Weller (2011, p. 77) has argued in the context of mental health, there is a need for a 'culture of supported decision-making' in the context of children's disability rights. This would at least be a move in the right direction.

\section{Acknowledgments}

I would like to thank the two anonymous reviewers for Social Inclusion for their very helpful comments on an earlier draft of this article.

\section{Conflict of Interests}

The author declares no conflict of interests.

\section{References}

Arstein-Kerslake, A., \& Flynn, E. (2016). The General Comment on Article 12 of the Convention on the Rights of Persons with Disabilities: A roadmap for equality before the law. The International Journal of Human Rights, 20(4), 471-490.

Badham, B. (2004). Participation-For a change: Disabled young people lead the way. Children and Society, 18, 143-154.

Banner, N. F. (2012). Unreasonable reasons: Normative judgements in the assessment of mental capacity. Journal of Evaluation in Clinical Practice, 18(5), 1038-1044.

Bartlett, P. (2012). The United Nations Convention on the Rights of Persons with Disabilities and mental health law. The Modern Law Review, 75(5), 752-778.

Bartlett, P. (2014). Implementing a paradigm shift: implementing the Convention on the Rights of Persons with Disabilities in the context of mental disability law. In Torture in healthcare settings. Washington: Centre for Human Rights and Humanitarian Law, American University Washington College of Law.

Besson, S. (2011). The principle of non-discrimination in the Convention on the Rights of the Child. In M. Freeman (Ed.), Children's rights: Progress and perspectives. Leiden: Martinus Nijhoff. 
Breen, C. (2005). Age discrimination and children's rights. Leiden: Brill.

Buck, T. (2011). International child law (2nd ed.). London: Routledge.

Cohen, E. F. (2005). Neither seen nor heard: Children's citizenship in contemporary democracies. Citizenship Studies, 9(2), 221-240.

Committee on the Rights of Persons with Disabilities. (2014). General comment No. 1 (2014) Article 12: Equal recognition before the law. CRPD/C/GC/1.

Committee on the Rights of Persons with Disabilities. (2016). General comment No. 4 (2016) on the right to inclusive education. CRPD/C/GC/4.

Committee on the Rights of the Child. (2003). General Comment No. 5 (2003) General measures of implementation of the Convention on the Rights of the Child. CRC/GC/5.

Committee on the Rights of the Child. (2006). General Comment No. 9 (2006) The rights of children with disabilities. CRC/GC/9.

Committee on the Rights of the Child. (2009). General Comment No. 12 (2009) The right of the child to be heard. $\mathrm{CRC} / \mathrm{GC} / 12$.

Connors, C., \& Stalker, K. (2007). Children's experiences of disability: Pointers to a social model of childhood disability. Disability and Society, 21(1), 19-33.

Dawson, J. (2015). A realistic approach to assessing mental health laws' compliance with the UNCRPD. International Journal of Law and Psychiatry, 40, 70-79.

Dhanda, A. (2007). Legal capacity in the Disability Rights Convention: Stranglehold of the past or lodestar for the future? Syracuse Journal of International Law and Commerce, 34, 429-462.

Dhanda, A. (2008). Constructing a new human rights lexicon: Convention on the Rights of Persons with Disabilities. International Journal of Human Rights, 8, 43.

Fineman, M. A. (2008). The vulnerable subject: anchoring equality in the human condition. Yale Journal of Law and Feminism, 20, 1-23.

Foucault, M. (1980). Power and strategies. In C. Gordon (Ed.), Michel Foucault power/knowledge: Selected interviews and other writings 1972-1977. London: Harvester Wheatsheaf.

Foucault, M. (1983). Afterword: The subject and power. In H. L Dreyfus \& P. Rabinow (Eds.), Michel Foucault: Beyond structuralism and hermeneutics. London: Harvester Wheatsheaf.

Foucault, M. (2006). Psychiatric power, lectures at the College de France 1973-1974. Basingstoke: Palgrave Macmillan.

Foucault, M. (2007). Security, territory, population lectures at the College de France 1977-1978. Basingstoke: Palgrave Macmillan.

Franklin, A., \& Sloper, P. (2009). Supporting the participation of disabled children and young people in decision-making. Childhood and Society, 23(1), 3-15.

Freeman, M. (2011). Why it remains important to take children's rights seriously. In M. Freeman (Ed.), Chil- dren's rights: Progress and perspectives. Leiden: Martinus Nijhoff.

Gabel, S., \& Peters, S. (2004). Presage of a paradigm shift? Beyond the social model of disability towards resistance theories of disability. Disability and Society, 19(6), 585-600.

Gadda, A. (2008). Rights, Foucault and power: A critical analysis of the United Nations Convention on the Rights of the Child (Edinburgh Working Papers in Sociology, No. 31). Edinburgh: University of Edinburgh.

Gallagher, M. (2008). Foucault, power and participation. International Journal of Children's Rights, 16, 395-406.

Harnacke, C. (2013). Disability and capability: Exploring the usefulness of Martha Nussbaum's capabilities approach for the UN Disability Rights Convention. Journal of Law and Medical Ethics, 41, 768-780.

Hart, R. (1992). Children's participation from Tokenism to citizenship. Florence: UNICEF Innocenti Research Centre.

Holroyd, J. (2012). Clarifying capacity: Value and reasons. In L. Radoilska (Ed.), Autonomy and mental disorder. Oxford: OUP.

Kanter, A. S. (2015). The development of disability rights under international law: From charity to human rights. Abingdon: Routledge.

Kirby, P., Lanyon, C., Cronin, K., \& Sinclair, R. (2003). Building a culture of participation: Involving children and young people in policy, service planning, delivery and evaluation. London: Department for Education and Skills.

Lansdown, G. (2005). The evolving capacities of the child. Florence: Innocenti Research Centre and Save The Children.

Lloyd, K., \& Emerson, L. 2016. (Re)examining the relationship between children's subjective wellbeing and their perceptions of participation rights. Child Indicators Research. doi:10.1007/s12187-016-9396-9

Lundy, L. (2007). Voice is not enough: Conceptualising Article 12 of the United Nations Convention on the Rights of the Child. British Educational Research Journal, 33(6), 927-942.

Mackenzie, C. (2014). Three dimensions of autonomy: A relational analysis. In A. Veltman \& M. Piper (Eds.), Autonomy, oppression and gender. Oxford: OUP.

Mégret, F. (2008). The Disabilities Convention: Human rights of persons with disabilities or disability rights? Human Rights Quarterly, 30, 494-516.

Nolan, A. (2010). The child as 'democratic citizen': challenging the 'participation gap'. Public Law (Winter), 767-782.

Oliver, M. (2013). The social model of disability: Thirty years on. Disability and Society, 28(7), 1024-1026. Richardson, G. (2012). Mental disabilities and the law: From substitute to supported decision-making? Current Legal Problems, 65, 333-354.

Sabatello, M. (2013). Children with disabilities: A critical appraisal. International Journal of Children's Rights, 21, 464-487. 
Series, L. (2015). Relationships, autonomy and capacity: Mental capacity and support paradigms. International Journal of Law and Psychiatry, 40, 80-91.

Shakespeare, T., \& Watson, N. (1997). Defending the social model. Disability and Society, 12(2), 293-300.

Sinclair, R. (2004). Participation in practice: Making it meaningful, effective and sustainable. Children and Society, 18(2), 106-118.

TenBroek, J. (2009). The United Nations Convention on the Rights of Persons with Disabilities: Toward a new international politics of disability. Texas Journal on Civil Liberties and Civil Rights, 15(1), 33-52.

Thomas, C. (1999). Female forms: Experiencing and understanding disability. Buckingham: Open University Press.

Thomas, N. (2007). Towards a theory of children's participation. International Journal of Children's Rights, 15(2), 199-218.

Tisdall, E. K. M. (2008). Is the honeymoon over? Children and young people's participation in public decisionmaking. International Journal of Children's Rights, 16(3), 419-429.

United Nations. (1989). United Nations convention on the rights of the child. New York: United Nations.

United Nations. (2006). United Nations convention on the rights of persons with disabilities. New York: United Nations.

VIPER. (2013). A literature review on the participation of disabled children and young people in decision making. London: Council for Disabled Children.

Watson, N. (2012). Theorising the lives of disabled children: How can disability theory help? Children and Society, 26, 192-202.

Weller, P. (2011). The Convention on the Rights of Persons with Disabilities and the social model of health: new perspectives. Journal of Mental Health Law, Spring, 74-83.

\section{About the Author}

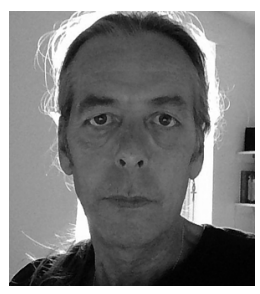

Ralph Sandland is Professor of Law and Difference in the School of Law, University of Nottingham. Ralph teaches and researches in the areas of family law, children's rights, healthcare law, mental health law, disability rights, gender and sexuality law. Ralph has published widely in all these areas. Recent output includes 'Lessons for Children's Rights from Disability Rights?' In E. Brems, E. Desmet, \& W. Vandenhole (Eds.), Children's Rights Law in the Global Human Rights Landscape (2017, Abingdon: Routledge). 